\title{
The Understanding of Islamic Management Practices among Muslim Managers in Malaysia
}

\author{
Mohamed Sulaiman ${ }^{1}$, Nur Arfifah Abdul Sabian ${ }^{1} \&$ Abdul Kadir Othman ${ }^{2}$ \\ ${ }^{1}$ Kulliyah of Economics and Management Sciences, International Islamic University Malaysia (IIUM), Gombak, \\ Malaysia \\ ${ }^{2}$ Faculty of Business Management, Universiti Teknologi MARA, Puncak Alam, Malaysia \\ Correspondence: Abdul Kadir Othman, Faculty of Business Management, Universiti Teknologi MARA, Puncak \\ Alam, 42300 Puncak Alam, Selangor, Malaysia. Tel: 60-3-3258-5004. E-mail: abdkadir@salam.uitm.edu.my
}

Received: October 14, 2013 Accepted: November 6, 2013 Online Published: December 31, 2013

doi:10.5539/ass.v10n1p189

URL: http://dx.doi.org/10.5539/ass.v10n1p189

\begin{abstract}
Islam is a comprehensive religion which covers every single aspect of human activity. Islam is not a religion that only focuses on the private life of individuals, but also covers and guides humans' interaction and activities in their daily lives. Despite the comprehensiveness of the Islamic teachings, limited studies have been conducted to examine the practice of Islam in the management of business processes in Muslim organizations. Therefore, this paper aims to investigate the understanding of Muslim managers regarding Islamic management in their organization. The study utilizes a qualitative research design by means of in-depth interviews with the selected Muslim managers from the prominent Muslim organizations in Malaysia. The findings of this study indicate that Muslim managers in Malaysia have great understanding of Islamic management practices and they have implemented these practices in their organizations. However, there is a great opportunity for improvement in the future with regards to Islamic management practices. The implication of this study is also discussed.
\end{abstract}

Keywords: Islamic management practices, Muslim manager, Malaysia

\section{Introduction}

As a religion, Islam brings a great impact on Muslims as human beings. It helps improve themselves to work and perform better (Mohiuddin, 2012). As a Muslim, the teachings and practices of Prophet Muhammad (Peace Be Upon Him) and his companions should be closely followed in the management of self, organization and even the state. Islamic management practiced by former Muslim civilization was so successful that the Muslims were able to conquer half of the world (Mohiuddin, 2007). However, the process of digging the lesson and principles requires an in-depth study of history and authenticity on the part of the person doing the work. Currently, studies done on the Islamic management can be considered as still lacking as compared to the western management literatures. Moreover, in contrast to Islamic economics and Islamic Banking and Finance (IBF), discussion and publications on Management from Islamic perspective (MIP) are rare (Ismail, 2012). For the purpose of this paper, management from Islamic perspectives is referred to as Islamic management.

In spite of the limited studies conducted in the Islamic management, still a growing number of Muslim organizations claim that they practice Islamic management in their daily business process, especially in Malaysia. A study conducted by Ilhaamie (2010) on Islamic human resource practices and organizational performance in Islamic organizations in Malaysia found that the overall implementation is moderate. However, the findings are questionable due to the understanding of the organization involved in the concept of Islamic management as a whole. Therefore, the objectives of this study are to investigate the understanding of Muslim managers regarding Islamic management concept in their organization and to examine the impact of the implementation on the employees and organizational performance.

\subsection{Statement of the Problem}

This study attempts to explore the understanding of Muslim managers on Islamic management concepts and practices. There are many important constraints in implementing the Islamic management concepts (Mohiuddin, 2009). One of them is the general people, even management experts are not well acquainted with this concept. Interestingly, Ahmad and Fontaine (2011) highlighted the importance of examining the Muslim managers' 
understanding of Islamic management concept.

"Few Muslims are well versed in management from an Islamic perspective, and the most accurate methods in achieving the objectives of the organization, business and non-business organizations alike. An individual may contribute accordingly in view of the operation and expected growth of the firm, but somehow, they may be working in a form of culture that is not encouraged by Islam. In other cases, Muslim may be competing healthily with one another in the firm, but somehow lacks the correct background knowledge and understanding of Islam. Thus, they may be carrying out tasks in a manner that is against Islam" (Ahmad \& Fontaine, 2011; p. 33).

Thus, the need to investigate the understanding and the application of Islamic management practices by Muslim managers has become crucial and urgent in order to be able to develop the Islamic management model in the future. In addition, this study attempts to reduce the gap by highlighting how well the manager comprehends and implements Islamic management in their organizations. Nowadays, apart from Islamic banking products, there is a remarkable rise in the production of foods which are claimed to be certified in Good Manufacturing Practice (GMP), covering all aspects of the production of halal foods, from preparation, handling to storage (Habibah, Anuar \& Rijal, 2008). Therefore, there is an urgent need to investigate the understanding of these managers on the concepts and practices of Islamic management.

\subsection{Objectives of the Study}

This paper aims to investigate the level of understanding of Muslim managers who practice Islamic management in their organizations. This study is significant to describe the development of Islamic management especially in the Malaysian context. Thus, it aims to find out the understanding of Muslim managers, which is in line with the literatures presented by scholars. What is their common understanding of Islamic management practice? What are the challenges they face? To what extent does the implementation of the Islamic management practices improve the performance of the organization? To answer these questions, this research is guided by the following research objectives:

1) To investigate the understanding of Muslim managers on the business management from the Islamic perspectives.

2) To examine the extent to which the Islamic management practices have been implemented in an organization.

3) To investigate the problems and challenges faced by Muslim managers in implementing Islamic management in their organizations.

4) To examine whether the Islamic management practices improve the performance of the employees and the organization.

\section{Management and Islamic Worldview}

\subsection{Islamic Management Defined}

Islam is a comprehensive, integrated and holistic religion that governs and interweaves all aspects of life (Ahmad, 2007). Besides, Islam not only concerns about the worldly matters but also the hereafter since everything done by mankind in this world has the ultimate end to seek Allah's pleasure. Therefore, to achieve the ultimate ends, man should follow the rules and guideline provided by the Almighty. The objective of man's creation is to worship Allah. It is clearly stated in the Holy Qur'an:

"And I (Allah) created not the jinn and mankind except that they should worship Me (alone)" (Holy Qur'an, 51:56).

Al-Attas (2001) claimed that everything in Islam is ultimately focused on the akhirah-aspect (the hereafter) without thereby implying an attitude of neglect or being unmindful of the duniya-aspect (worldly).

Since management is a daily process in the organization of various types, it is important to have the right definition of management according to the Islamic worldview. Basically, the Tawhidic approach is needed for the Islamization of the management concept so as to impose justice and fairness in managing people as the aim of man's creation (Jabnoun, 1994; Abdul Hamid, 2007) is to worship no other gods but Allah the Al-Mighty with the objective of managing people is to seek mardhatillah (Allah's pleasure) (Nordin \& Othman, 2011).

Islamic management means conducting activities depending upon the guidance of Allah (SWT) and following His prophet (Peace Be Upon Him) with an accountable mentality, integrity and skills to achieve a predetermined objective (Mohiuddin, 2012). Every human being shares the same relationship with Allah and His universe, a definite relationship between man and man is also prescribed as the relationship of brotherhood and equality 
(Mohiuddin, 2012). It is supported by Safiullah (2005) by giving an analogy of Tawhid as a coin with two faces: one implies that Allah is the Creator and the other implies that men are equal partners or that each man is brother to each other.

In defining management from an Islamic perspective, this study would highlight a definition by Mohiuddin (2009), who mentioned that management in the perspective of the Al-Quran and Al-Hadith or Islamic management is the process of planning, organizing, leading and controlling the efforts of organizational members and by using all other organizational resources depending upon the guidance of Allah (SWT) and His Prophet (Peace Be Upon Him) with accountable mentality, integrity and skills to achieve the predetermined objective.

\subsection{Islamic Management Based on Tawhidic Worldview}

A study conducted by Sharif and Ismail (2011) concluded that the transformation of Islamic management systems within the Tawhidic paradigm harmonizes the spirit of Tawhid (Unity of God) with planning, organization, leading and controlling. The managerial functions are integrated with both the hereafter (al-Akhirah) and the world (Al-Duniya) requirements. With this spiritual awareness, the evolving and continuing management system will achieve the firm's mission and objectives by implementing mutually reinforcing values referred to as promotion of goodness ('amr bil ma'aruf) and the prevention of evil (nahi 'Anil munkar). Their proposed framework suggests that continuous learning of both the Deen and one's career is an important requirement for the successful implementation of the all-in-one existence of a firm.

Referring to figure 1, there are three main components of the Islamic worldview; Tawhidic Paradigm, roles/duties and core values. Tawhidic paradigm reflects true submission to Allah and absolute devotion to His Commandments. As a consequence of the recognition of kalimah shahaada, man has to recommence two fundamental yet interrelated roles, which are the servant and vicegerent of Allah. The roles must be executed with due diligence - trust and justice (Ismail \& Sharif, 2011). Allah mentioned in the Holy Qur'an in Surah Al-Talaq: 3:

"And He provides for him from (sources) he never could imagine. And if anyone puts his trust in Allah (SWT), sufficient is (Allah) for him, for Allah (SWT) will surely accomplish His purpose verily for all things has Allah (SWT) appointed a due proportion" (Holy Qur'an, $65: 3)$.

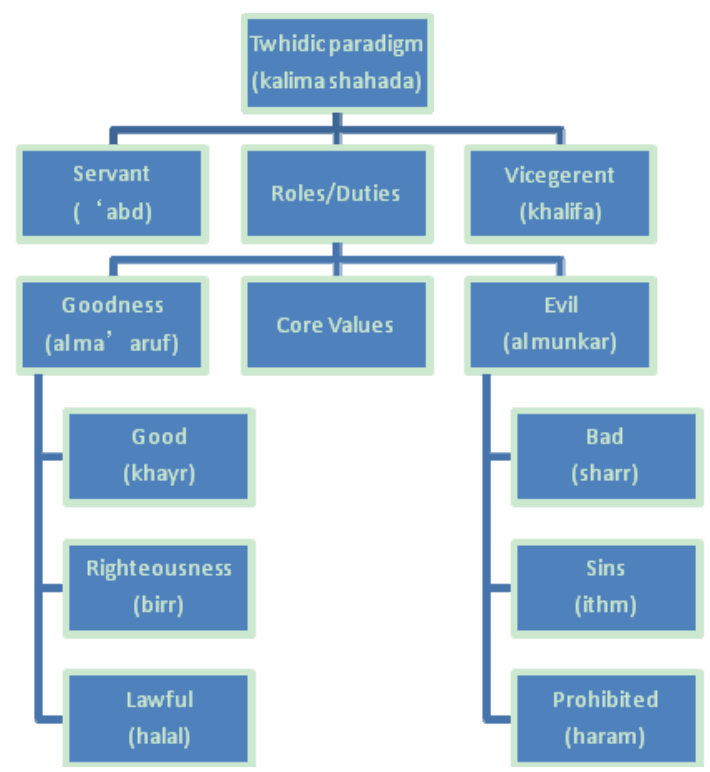

Figure 1. Fundamental principles of Duniyawi-Ukhrawi view

The concept of Tawhid guides a manager to be able to perform his obligations along with his subordinates and to be a good leader so that the subordinates may strive to serve their best together in their works. Ismail and Sharif 
(2011) again proposed a summary of the roles of Tawhidic Paradigm in the transformation of the management system as follows:

Table 1. Summary of components of Tawhidic paradigm (TP) and managerial functions (MF)

\begin{tabular}{|c|c|c|}
\hline Tawhidic components & Managerial Functions & Illustration \\
\hline \multirow{4}{*}{$\begin{array}{l}\text { Servant of Allah and } \\
\text { vicegerent (trust, justice, } \\
\text { promoting goodness, and } \\
\text { preventing evil) }\end{array}$} & Planning & $\begin{array}{l}\text { SA (servant of Allah) - P applies Tawhidic values of } \\
\text { setting goals, strategies and decision }\end{array}$ \\
\hline & Organizing & $\begin{array}{l}\text { SA-O applies Tawhidic value via iman, 'amal and } \\
\text { fahm in assigning tasks and arranging resources }\end{array}$ \\
\hline & Leading & $\begin{array}{l}\text { SA-L applies iman and 'ibadah in influencing and } \\
\text { motivating people }\end{array}$ \\
\hline & Controlling & SA-C applies thrust (al-amanah) and justice ( $a l$ - 'adl) \\
\hline
\end{tabular}

A Muslim manager should act as a trustee of Allah in carrying out his duties in organizations. He needs to make sure all his formulations, execution, and evaluation of plans, organizing tasks and resources, leading workforce, and controlling resources-goals are consistent with Tawhid and the specific principles of Islam (Ismail \& Sharif, 2011).

\subsection{Islamic Management versus Conventional Management}

The main differences between Islamic management and conventional management are highlighted by Kazmi (2004) in his work entitled "A Preliminary Inquiry into the Paradigmatic Differences among the Conventional and Islamic Approaches to management studies" (Kazmi \& Ahmad, 2006). The following table presents the differences between the two concepts of management.

Table 2. The main differences between Islamic and conventional management

\begin{tabular}{|c|c|c|}
\hline Criteria differences & Islamic management & Conventional management \\
\hline $\begin{array}{lr}\text { Paradigm } & \text { guiding } \\
\text { management } & \text { of } \\
\text { organizations } & \end{array}$ & $\begin{array}{l}\text { No demarcation between the secular and } \\
\text { the religious; human life is an organic } \\
\text { whole; All human activity can be Ibadah } \\
\text { provided they are guided by Allah's } \\
\text { commandments. }\end{array}$ & $\begin{array}{l}\text { A clear demarcation between the secular } \\
\text { and the religious; human activities are } \\
\text { separated; spiritual or religious aspect is a } \\
\text { private matter of individuals while work is } \\
\text { in the public domain. }\end{array}$ \\
\hline $\begin{array}{lr}\text { Purpose of } & \text { human } \\
\text { existence } & \text { dictating } \\
\text { management } & \text { of } \\
\text { organizations } & \end{array}$ & $\begin{array}{l}\text { The purpose of human existence is to } \\
\text { obey and fulfil Allah's commandments } \\
\text { and act as the vicegerent of Allah on } \\
\text { earth. }\end{array}$ & $\begin{array}{l}\text { The purpose of human existence is to } \\
\text { utilize natural resources to satisfy one's } \\
\text { needs, wants and desires and to remain } \\
\text { happy. }\end{array}$ \\
\hline $\begin{array}{l}\text { Purpose } \\
\text { organization }\end{array}$ & $\begin{array}{l}\text { Organization is meant to be groups of } \\
\text { people coming together to attain the } \\
\text { purpose of human existence. }\end{array}$ & $\begin{array}{l}\text { Organizations are meant to be groups of } \\
\text { people coming together to attain the } \\
\text { organizational goals. }\end{array}$ \\
\hline $\begin{array}{l}\text { Nature } \\
\text { organizational } \\
\text { objectives }\end{array}$ & $\begin{array}{l}\text { Organizational objectives are both } \\
\text { economic and non-economic and are } \\
\text { subservient to the larger purpose of } \\
\text { human existence. }\end{array}$ & $\begin{array}{l}\text { Organizational objectives are both } \\
\text { economic and non-economic in nature and } \\
\text { are subservient to organizational interest. }\end{array}$ \\
\hline $\begin{array}{l}\text { Source of ethics and } \\
\text { values governing } \\
\text { management of } \\
\text { organizations }\end{array}$ & $\begin{array}{l}\text { The revealed knowledge (Al-Qur'an) and } \\
\text { the traditions of the prophet (Peace Be } \\
\text { Upon Him) constitute the ultimate } \\
\text { sources of business ethics and personal } \\
\text { values. }\end{array}$ & $\begin{array}{l}\text { Ethics is relative and values are derived } \\
\text { from multiple sources such as upbringing, } \\
\text { society, and experiences. Ethics could be } \\
\text { relative as in utilitarian theory. }\end{array}$ \\
\hline Organizational Control & $\begin{array}{l}\text { Organizational control has to operate in a } \\
\text { way designed to make the human being } \\
\text { subservient to the will of Allah (SWT). }\end{array}$ & $\begin{array}{l}\text { Organizational control has } \\
\text { way designed to align hur } \\
\text { with the organizational obje }\end{array}$ \\
\hline Locus of control & The locus & 1 is external and lies in \\
\hline
\end{tabular}


his actions in the hereafter.

Organizational responsibility accountability
The human being has choice, free will and and freedom of action and therefore is responsible and accountable for all actions. the realm of the organization.

Responsibility and accountability are vested in the chief executive who delegates them. Employees are controlled through organizational systems to ensure responsibility and accountability.

Source: Kazmi and Ahmad (2006)

Generally, by referring to table 2, Islamic management brings huge differences as compared to the conventional management. It is not only based on leadership, the principles of managing organization such as planning, organizing, leading and controlling. Whenever these concepts are applied following Islamic belief and principles, they are termed as Islamic management (Mohiuddin, 2009).

\subsection{Concept of Falah and Rizq}

These two concepts are among the important concepts in Islamic management, implying what are the success and gain that should be expected by a Muslim. The success from the eyes of Islam is more comprehensive and beyond the meaning of the words 'success' itself. From the five-time-a-day calls of the prayer, Muslims are reminded to strive to achieve Falah (success). According to Ahmad (2007), the word Falah is a very complex and rich word, in which its meaning goes beyond what is defined by success in the mainstream. It is defined as the everlasting prosperity and blessing. Khalifa (2001) argued that the word Falah exists in four dimensions:

1) A dynamic dimension (strive to thrive)

2) A universal dimension (to attain 'Falah' implying that the endeavors of one's entire life is considered)

3) An ethical dimension (to be righteous, in intentions and deeds, to be blessed)

4) A continuity dimension (the fruits or the consequences of Falah are enjoyed both in the worldly life and most importantly in the hereafter).

Again, he argued that all human efforts in these worldly activities for the sake of Allah's pleasure should be regarded as integrated elements towards the accomplishment of Falah as the ultimate goal of life (Khalifa, 2001).

Another important term is Rizq. Based on the Arabic word translation, Rizq includes whatever is of beneficial use and bestowal of something by Allah. Kahf (1996) as cited by Ahmad (2009) pointed out Yusuf' Ali's translation of the Qur'an, the word of Rizq refers to following meanings, Godly sustenance, Divine bestowal, Godly provision and Heavenly gifts, which in summary reflect that "all these meanings convey the connection to Allah as the true Sustainer of and Provider for all His creatures". Rizq plays a better role as an alternative to profit maximization (Khalifa, 2001). As compared to conventional definition of profit maximization, Rizq enlargement reflects more than materialistic gain because it is based on Taqwa (Piety) and Tawakkul (putting one's trust on Allah).

\subsection{Findings in Current Literature}

A recent study conducted by Mohiuddin (2012) introduces a new concept of Islamic management as well as a model which is applicable to all organizations, in general, and to managers in the Islamic world, in particular. It was found that relatively committed Muslims behave and perform (function) better than relatively less-committed Muslims working in different banks of Bangladesh and Malaysia. The results of the empirical study show that Relative Committed Muslims (RMCs) make more effective decisions than Relative Less Committed Muslims (RLCMs). Moreover, the analysis of variance shows that there are significant differences between RCMs and RLCMs in relation to the joint effect of degree of religious commitment and age of the employee. Mohiuddin concluded that the RCM's greater knowledge of and commitment to his religion permitted him to think and behave according to the Islamic managerial model by applying Islamic managerial concepts of consultation and Shura in making decisions. Through the delegation of authority, it is evident that RCMs are more capable in effectively delegating their authority than RLCMs (Mohiuddin, 2012).

\subsection{Problems and Challenges}

According to Loqman and Bubul (2011), most of the concepts of conventional management are present in the Islamic management approach. Besides, Islamic management system has its own uniqueness, which demonstrates that it is more applicable and acceptable to people. Unfortunately, these authors claimed that the 
present situation still does not support the concept in the literature because the managers do not strictly adhere to the basic rules of Islamic guidelines. Junaidah (2011) also asserted that managers and employees are not following the Islamic teachings and do not behave according to what has been taught by Al-Qur'an and As-Sunnah of Prophet Muhammad (Peace Be Upon Him). Moreover, they tend to use religion as an excuse. Some of them are Muslims only by their name and their knowledge about Islam is only superficial. They also think that work does not relate to their belief as a Muslim which causes them to misunderstand what Islam is.

\subsection{Impact of Islamic Management on Performance}

An empirical study conducted in Bangladesh by Hossain (2011) concluded that the more the manager applies the Islamic principles of management, the more effective the organization becomes. Hossain (2011) observed that the growth of an organization relies on knowledge and discipline which are translated through solah (prayers), unified efforts, $A l-A d l$ (justice), payment of remuneration and other Islamic management principles. He found that there is positive relationship between performance and knowledge and principles of Islamic management practiced by the studied organizations.

\section{Research Participants}

A sample of seven experienced practitioners from well-known private Muslims institutions and SMEs (Small Medium Enterprise) were selected through a purposive sampling technique, which is based upon criteria which may include specialist knowledge of the research issues, or capacity and willingness to participate in the research (Oliver, 2006). Referring back to the objective of the study, Muslim managers were selected in order to get their opinions and understanding on Islamic management practices. Table 3 shows the list of respondents.

Table 3. List of respondents

\begin{tabular}{lllcc}
\hline Respondent & Gender & Title and organization & Age & Work Experience \\
\hline Respondent 1 (R1) & Male & Assistant Vice President/ Private Takaful Company & 32 & 7 years \\
Respondent 2 (R2) & Male & Manager/ Islamic Bank & 31 & 7 Years \\
Respondent 3 (R3) & Female & Human Resource Manager/ SME & 33 & 9 years \\
Respondent 4 (R4) & Male & Operation Manager & 31 & 7 years \\
Respondent 5 (R5) & Male & Managing Director/ SME & 27 & 3 Years \\
Respondent 6 (R6) & Male & Branch Manager/ Islamic Bank & 48 & 23 years \\
Respondent 7 (R7) & Male & Branch Manager/Islamic Private Institution & 55 & 30 years \\
\hline
\end{tabular}

\subsection{Data Collection Process}

The data collection process involved face to face in-depth interviews for which appointments had been set before the meeting. The interview used semi-structured set of questions as a guide. Then, the findings from the interviews were transcribed and coded into a set of themes. The interview took approximately 30 to 45 minutes.

\section{Findings and discussion}

This section presents the feedback of the informants about their understanding of Islamic management and its practices in their organizations. Based on the research objective, the findings are divided into four main themes.

\subsection{Understanding of Islamic Management}

The first objective of this research is to see whether Muslim managers understand the meaning of Islamic management. It is very important that they should to be able to differentiate it from conventional management. A simple question was asked to every respondent about his or her understanding on Islamic management concepts and practices. Most of the respondents highlight that the Islamic management should be based on the Al-Quran and As-Sunnah. Respondent 1 stated that Islamic management is based on Islam as a comprehensive way of life, which is reflected not only on the products or services offered but also the whole process from A to Z, which involves all stakeholders who must also comply with the Shariah. Again, he gave the example of his company's vision that contains objectives that reflect both success in this world and hereafter. He believed that as business entity, the organization needs to maximize profits, improve its reputation but at the same time the actions must be guided by Islamic rules and principles.

Respondent 5 described that Islamic management basically concerns on how the practice and decision making 
made in the business follow what has been stated in the Al-Quran and practiced by Prophet Muhammad (Peace Be Upon Him). Respondent 7 stated:

"Islamic management is based on Syariah and should manage according to the Al-Quran and As-Sunnah."

He kept on focusing on three main questions, which are; from where we are, where we are right now and what our end is, which reflect the importance of concept Tawhid and belief in the day of judgement. According to respondent 7, as a Muslim manager, by always answering these three questions will help and guide him or her to manage the organization successfully. Recalling how Mohiuddin (2009) defined Islamic management, he mentioned that Islamic management is the management from the perspective of Al-Quran and Al-Hadith or the whole process of management including organizational resources depend on the guidance of Allah (SWT) and His Prophet (Peace Be Upon Him) with accountable mentality, integrity and skills to achieve predetermined objectives.

Moreover, Respondent 1 highlighted the importance of the Al-Falah concept, which emphasizes success in this worldly life as well as success in the hereafter.

"...not only we want to be successful in this world, known with our best performance and profitable company and have a good reputation but also we want to ensure our profit gained can bring profit for us in the hereafter as well..."

Respondent 6 mentioned about the difference of income gained and the concept of Rizq according to Islam, which must also meet the halal requirements. Supported by Respondent 5, the 'barakah' of the Rizq is very important. 'Barakah' is the extra or additional outcome (Rizq) provided by Allah because of good deeds done.

Basically, all the participating managers agreed that the main purpose of human existence in organization is to serve the Allah commandments and act as vicegerent of Allah on earth. It appears that Malaysian Muslim managers have fair understanding of Islamic management.

\subsection{Applications of Islamic Management}

All respondents mentioned that they provided sufficient time and place for their employees to perform their religious duties such as time for prayers. However, Respondent 2 stated that the concepts of 'amanah (trustworthiness) and strive for excellence are their main concern with regards to performing daily work activities. He said that there are two main things that are closely related to staff; talent and attitude.

"It is very important to develop the staff's attitude first."

According to him, in order to develop the right attitude and values among the staff, it is important to create a good environment:

“We acknowledge our employees' points of view. I believe as a manager, by fulfilling the employees' needs we help them to perform better. As what has been implemented by our department, every two weeks we have our internal meeting, which are called "Muhasabah or Reflection". My subordinates are allowed to share their problems or constraints and raise their dissatisfaction in order to improve the work process in the future. For example, from that meeting, we apply job rotation as suggested by one of my subordinates in order to make them more multi-tasking and efficient."

Above statement was supported by Respondent 6 who emphasized that the role of managers is to help their subordinates create the Islamic environment. He said:

"It was like performing solah, as a manager, we cannot only ask them to do it, we must provide the time and facilities..."

Respondent 1 stated that in implementing Islamic management, the two important things must be closely followed, which are Sunnatullah and Shariahtullah. Sunnatullah, according to him, is that anything that requires a manager to perform his duty such as planning, organizing, leading and monitoring. The works should be executed as best as he can. It also includes how to strategize the business and convince the potential clients. He gave the example of the time of Prophet (Peace Be Upon Him) during the cases of Hijrah and the battle of Uhud.

"A good strategy only cannot guarantee the victory of battle of Uhud because some of the companions did not obey the instructions of the Prophet. Shariahtullah is at the same time after we serve our best... then... it must be followed by what is allowed by Allah (SWT). We cannot exaggerate our product advertisement more than what it should be. We must be honest while dealing with our clients as we believe everything that we do in this duniya will be asked in the hereafter." 
Referring to the basic attire requirement as Muslim employees or employers should adhere to while working, most of the respondents emphasized their agreement on the obligation. They agree that by following basic requirement in Islam for covering 'aurat' (Islamic dressing requirement) helps in creating good environment and respect for each other.

Another thing that was highlighted by some respondents is the importance of disseminating knowledge among the staff. For example, Respondent 1, Respondent 2, Respondent 4, and Respondent 5 mentioned that there are regular Tazkirah sessions held on daily, weekly and monthly basis and organized by the management in order to enhance and continuously remind their staff regarding Islamic understanding and knowledge. Moreover, they had active involvement of the staff for this purpose. For example, Respondent 4 said:

\section{"We have our Muslim welfare unit called "Persatuan Kebajikan Muslim" (Association for Welfare of} Muslim), which is responsible for organizing such programs."

In addition, Respondent 5 emphasized the importance of creating 'Biah Solehah' (good environment, which is according to Islamic values) and increasing the Islamic understanding among his staff through 'Halaqah or Usrah' (dicussion or talks), which were organized weekly for them.

Besides, during the recruitment of new employees, the basics of Islamic understanding had great influence on the decision on who should be selected. For example, Respondent 3 stated:

"I basically don't believe in selecting a person just based on the first impression. As a Human Resource manager, usually during the interview session, I will test the candidate by asking unexpected questions such as 'are you married? If not, do you have a girlfriend? How did you meet her? I will ask them informally to know how far they are committed to the Islamic teachings. Another thing that I always do, I purposely drag the interview session until the prayer time to see their reactions."

Respondent 1 affirmed that, in every interview session to recruit new employees, a member from Shariah department will sit as one of the interviewers. There are basic questions that must be asked to the candidates to see their level of understanding and willingness to be committed to the Islamic principles, rules and regulations. Besides, within the organization, the Shariah department conducts internal audit on the selected department every month to ensure the work decision and process comply with the Shariah.

\subsection{The Problems and Challenges}

As described by the respondents, most of the problems or challenges faced by these managers are related to the degree of understanding on the Islamic management concepts and practices. Respondent 6 raised the issues of dealing with different levels of understanding, which relate to the background of the staff. According to him, although all of his employees are Muslim, they do not have the same background of Islamic teachings. Besides family, their educational background also plays an important role in shaping their understanding. Therefore, as a manager, it is very important to be creative in dealing with the staff so that they can have better understanding of Islam. As for Respondent 1, handling new employees is quite challenging. According to him, some of the new entrants had already been practicing conventional management system for more than 10 years. Therefore, the time taken for them to understand the Islamic management practices should be considered. He added:

"Another challenge is high workload that prevents the employees from attending programs organized to enhance Islamic teachings and understanding."

Respondent 3 mentioned the challenge when they faced a conflict of interest between preserving the Islamic principles and the element of commerce while making a business decision. Some of the elements of commercialization that are accepted by Islamic teachings can be used. If the company only focuses on profit, there were lots of businesses offered to them that did not comply with the Al-Qur'an and As-Sunnah requirements. She shared one of her experiences;

"I remembered that one day we got an offer to publish books of which the owner promised to give huge commission to our company. However, when we reviewed the book, there was a lot of misleading information that can bring bad influence to society. Then, we decided to reject the business offered."

On the other hand, Respondent 4 faced some problems from the top management who did not support any program that can help to increase the staff's Islamic understanding. His employer did not agree with the time provided for the staff to pray because to him it was a waste of time. He added by citing another challenge that the staff had to face:

"Whenever we organized awareness programs or congregational prayers roughly about 50 out of 800 plus staff would be committed and interested to join the programs..." 
In dealing with the challenges in practicing Islamic management, Respondent 6 mentioned that he needs to be creative when dealing with new generations so that they can easily accept advices and dissemination of the Islamic knowledge. Respondent 2 and Respondent 7 shared the same response to the question related to problems and challenges of practicing Islamic management. Both of them did not have any problem related to those issues as long as there is a good communication with the staff.

\subsection{The Impact of Islamic Management on Performance}

The respondents agreed that Islamic management provides a positive impact on the performance of employees as well as the organization. According to Respondent 1, the application of Islamic management and conventional management practices does not differ significantly in terms of performance. However, there are huge differences with regards to values and ethics, awareness, and discipline which come from inside the man himself, for example, the awareness that there is God or Allah, sin and rewards are from Allah. Respondent 3 replied as follows:

"Of course there is an impact on the employee performance. From my observation, those who are punctual with their solah will always have discipline with their work and time. I have experience with some employees who always delay their solah. At the end of the day, they are always unable to finish their work and drag it to the next day. They always come up with many excuses. Therefore, I really believe that our commitment with religious duties is translated in our commitment to our work because working is also part of Ibadah..."

According to Respondent 5, the impact of the Islamic management practices is on commitment and willingness to sacrifice and loyalty.

"We started with a salary of only RM 200 per month, along the way we grew and Alhamdulillah now we managed to have two offices and increase the salary. But, still it is below RM 1000. There was a time we could not afford to pay salaries. Interestingly, none of my team or employees complained. But, from my part, I will ensure that they get their salary on time and accordingly with the profit that the company makes.'

On the practice of Islamic management in his organization, Respondent 7 stated that both managers and employees practiced the "concept of itqan" in their works by doing their best because of Allah since work is considered as ibadah. Affirmed by Respondent 6 who agreed that Islamic management brings significant and positive impact to the performance, he mentioned:

"Yes, I agree that it improves the performance. As you can see our company's performance is improving from year to year."

To sum up, the implementation of Islamic management will help organizations to not only gain profit but also improve values through the behavioral reflection of the people within the organization. It will influence the whole performance of the organization internally and externally.

\section{Conclusion and Recommendations}

From the results of the study, it can be concluded that there are improvements in the understanding and practice of Islamic management among Muslim managers as compared to a study conducted by Kazmi (2013). Most of the managers interviewed were aware about Islamic management. Some of them showed deep understanding of Islamic management when answering the questions. They can relate the management process with the Quranic verses and provide examples from the Seerah (history) of Prophet Muhammad (Peace Be Upon Him) while explaining their opinions.

Islamic management is a specific approach developed according to the Islamic principles, which guide the managers in managing the organization. It started with setting the organizational objectives, vision and mission, company's values, code of conduct and ethics, the process of decision making, recruitment, employees training and developments and strategies in managing the business. The findings can be integrated with the proposed components of Tawhidic paradigm (TP) and managerial functions (MF) as proposed by Ismail and Sharif (2011) for further empirical research.

The problems and challenges raised by the respondents revolve around the importance of disseminating the Islamic teachings and knowledge to employer and employee in order to increase their understanding on Islamic management and its practices. It is important to note that from the findings, there is evidence showing that by practicing Islamic management, the organization can experience an increase specifically in employees' performance and generally in the organizational performance. 
Pertaining to the implication for future research, it would be fruitful if future research could have a bigger sample of Muslim managers and Muslim-managed organizations involved in the study. Besides, quantitative studies can be conducted using structured questionnaire to validate the findings from the present studies using both perspectives of the employees and the employers. The researchers hope that these findings can contribute a humble way to the development of Islamic management literature.

\section{References}

Abdul Hamid, A. S. (2007). Islamic perspectives on management: What we need to know and Why. Keynote Speech: AIM Asian Business Conference. Manila, Philippines, March 2007.

Ahmad, K. (2007). Management from Islamic perspective, principles and practices. Kuala Lumpur: International Islamic University of Malaysia Research Center.

Ahmad, K., \& Fontaine, R. (2011). Management from an Islamic perspective. Kuala Lumpur, Malaysia: Pearson Prentice Hall.

Al-Attas, S. M. (2001). Prolegomena: To the metaphysics of Islam. An exposition of the fundamentals of the worldview of Islam. Kuala Lumpur, Malaysia: International Institute of Islamic Thought and Civilization.

Azmi, I. A. G. (2010). Islamic human resource practices and organizational performance: A preliminary findings of Islamic organization in Malaysia. Journal of Global Business and Economics, 1(1), 27-42. Retrieved from http://EconPapers.repec.org/RePEc:grg:01biss:v:1:y:2010:i:1:p:27-42

Fontaine, R. (2011). Management models from an Islamic perspective. In A. M. Osman-Gani, \& S. M. Sharif (Eds.), Spirituality in management from Islamic perspectives (pp. 287-316). Kuala Lumpur, Malaysia: International Islamic University of Malaysia Press.

Hashim, J. (2011). Human resource practices in Islam and organizational outcomes. In A. M. Osman-Gani, \& S. M. Sharif (Eds.), Spirituality in management from Islamic perspectives (pp. 55-86). Kuala Lumpur, Malaysia: International Islamic University of Malaysia Press.

Hossain, M. M. (2012). Case studies of Muslim managed organizations in Bangladesh. In K. Ahmad, R. Islam, \& Y. Ismail (Eds.), Issues in Islamic management: Theories and practices (pp. 451-464). Kuala Lumpur, Malaysia: International Islamic University of Malaysia Press.

Ismail, Y. (2012). A proposed approach to the development of Islamic management as Discipline. In K. Ahmad, R. Islam, \& Y. Ismail (Eds.), Issues in Islamic management: Theories and practices (pp. 15-28). Kuala Lumpur, Malaysia: International Islamic University of Malaysia Press.

Ismail, Y., \& Sharif, S. M. (2011). The role of Tawhidic paradigm in the transformation of management system. In Z. A. Ghani, M. A. Hassan, M. R. M. Jailani, \& K. Othman, Proceeding of the National Seminar on Islamic Management System Transformation (Trans-SPI) organized by Islamic Science University Malaysia (USIM), PWTC, Kuala Lumpur, 1-2 October, 2011.

Jabnoun, N. (1994). Islam and Management. Kuala Lumpur, Malaysia: Institut Kajian Dasar.

Kahf, M. (1996). Profit distribution in Islamic banks. Review of Islamic Economics Studies, 3(2), 113-140.

Kazmi, A. (2004). A preliminary inquiry into the paradigmatic differences among the conventional and Islamic approaches to management studies. Unpublished Paper, Kuala Lumpur, Malaysia: International Islamic University of Malaysia.

Kazmi, A., \& Ahmad, K. (2006). Management from Islamic perspective. Kuala Lumpur, Malaysia: International Islamic University of Malaysia Press.

Kazmi, A., \& Ahmad, K. (2012). Managing from Islamic perspectives: Some preliminary findings from Malaysian Muslim-managed organizations. In K. Ahmad, R. Islam, \& Y. Ismail (Eds.), Issues in Islamic management: Theories and practices (pp. 440-450). Kuala Lumpur, Malaysia: International Islamic University of Malaysia Press.

Khalifa, A. S. (2001). Towards and Islamic foundation of strategic business management. Kuala Lumpur, Malaysia: International Islamic University of Malaysia.

Loqman, M., \& Bulbul, A. (2012). Convergence and divergence between conventional approach and Islamic approach to management. In K. Ahmad, R. Islam, \& Y. Ismail (Eds.), Issues in Islamic management: Theories and practices (pp. 2-14). Kuala Lumpur, Malaysia: International Islamic University of Malaysia Press. 
Mohiuddin, G. M. (2009). Islamic management. Dhaka, Bangladesh: University Grants Commission of Bangladesh.

Mohiuddin, G. M. (2012). Management views in Islamic literature: A conceptual analysis on the way of new management dimension. International Journal of Management, 3, 411-424.

Noordin, F. M., \& Othman, R. (2012). Islamic management: A citation analysis. In K. Ahmad, R. Islam, \& Y. Ismail (Eds.), Issues in Islamic management: Theories and practices (pp. 38-52). Kuala Lumpur, Malaysia: International Islamic University of Malaysia Press.

Talib, H. A., Ali, H. M., Jamaludin, K. A., \& Rijal, K. (2008). Quality assurance in halal food manufacturing in Malaysia: A preliminary study. In the International Conference on Mechanical \& Manufacturing Engineering (ICME2008), 21-23 May 2008, Johor Bahru.

Yusuf 'Ali, A. (2009). The meaning of the Holy Quran: Text translation and commentary. Kuala Lumpur, Malaysia: Islamic Book Trust.

\section{Copyrights}

Copyright for this article is retained by the author(s), with first publication rights granted to the journal.

This is an open-access article distributed under the terms and conditions of the Creative Commons Attribution license (http://creativecommons.org/licenses/by/3.0/). 